\author{
E. Del Guacchio, P. Cennamo, L. Paino \& P. Caputo
}

\title{
Further remarks on the narrow endemic Centaurea pandataria (Asteraceae, Cardueae)
}

\begin{abstract}
Del Guacchio, E., Cennamo, P., Paino, L. \& Caputo, P.: Further remarks on the narrow endemic Centaurea pandataria (Asteraceae, Cardueae). - Fl. Medit. 31 (Special Issue): 469-475. 2022. - ISSN: 1120-4052 printed, 2240-4538 online.

Centaurea pandataria is a very narrow endemic with unclear taxonomy and some uncertainness even about its nomenclature. In this contribution, the correct authorship of the basionym $C$. cineraria var. pandataria Bég. \& Fiori ex Fiori is clarified and, as a consequence, the recent lectotypification of the name is re-examined, resulting fully acceptable. Founding on the review of bibliographic data and on herbarium and field observations, a treatment at species-level is deemed the most consistent. Authors also report the first chromosome count of $C$. pandataria, which is diploid $(2 n=18)$, as the close $C$. aeolica.
\end{abstract}

Key words: Mediterranean flora, Tyrrhenian islands, taxonomy.

\section{Introduction}

In the framework of our researches about the flora of the Tyrrhenian islands (e.g., Cennamo \& al. 2013; De Castro \& al. 2013; Vallariello \& al. 2016; Iamonico \& al. 2017; Del Guacchio \& al. 2020), we refer here some issues on the controversial nomenclature and taxonomy of Centaurea pandataria (Bég. \& Fiori ex Fiori) Bég., endemic to Ventotene island, anciently named Pandataria (Pontine archipelago, Latium, central Italy).

Béguinot (1902) first wrote about this plant, enlightening its peculiar morphological features by reporting it as “Centaurea aplolepa var.”. Despite his opinion (Béguinot 1905: 443), however, he was not the first collector, as the plant had been already gathered on the island by G. Gussone (Fig. 1) in 1834 (Grande 1924: 115-116). This population was described as a new variety of $C$. cineraria L., i.e., C. cineraria var. pandataria Bég. \& Fiori ex Fiori (1904a: 334), even if raising some doubts (Fiori 1904b). However, Béguinot (1905) himself raised it to the species rank and interpreted $C$. pandataria (Fiori) Bég. as a microspecies of the fragmented $C$. cineraria group. Later, Fiori (1927) fully included C. cineraria var. pandataria in C. cineraria var. aeolica (Guss. ex Lojac.) Fiori. Also Grande (1925), Béguinot (1931) himself and Zangheri (1976) included $C$. cineraria var. pandataria in C. aeolica Lojac., without recognizing any taxonomic distinction. The same opinion was expressed by Cela Renzoni \& Viegi (1982) and Anzalone (1984: 126), while Dostál (1976) regarded the taxon as one of the several subspecies of C. aplolepa Moretti 
470 Del Guacchio \& al.: Further remarks on the narrow endemic Centaurea pandataria...

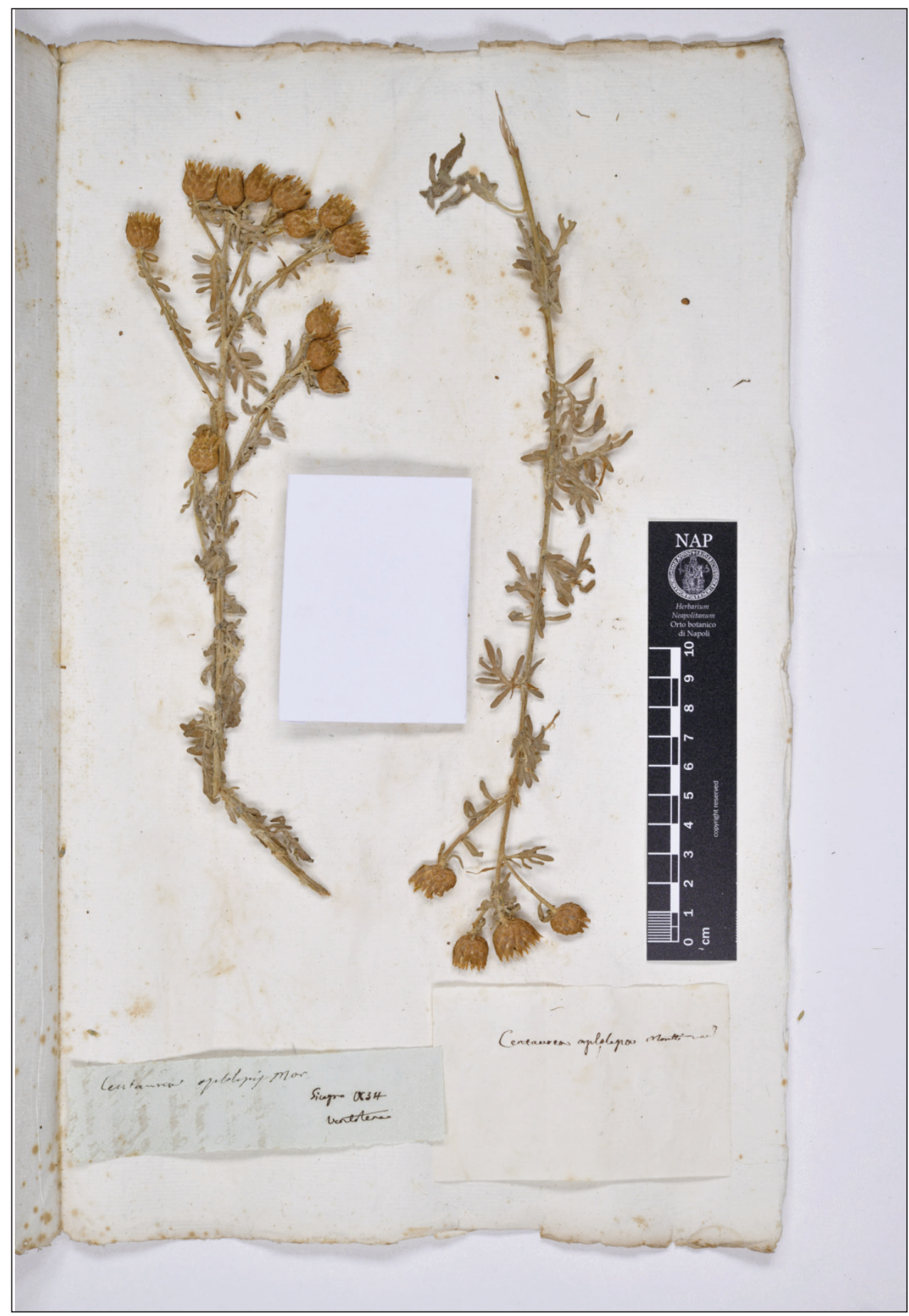

Fig. 1. A specimen of the first gathering of $C$. pandataria (NAP-“Gussone Generale" collection). 
(1826: 154). Anzalone (in Anzalone \& Caputo 1976: 82-83) and Pignatti \& Lausi (1982: 193) re-proposed the first treatment by Fiori (1904a). Nevertheless, later Anzalone (1995) preferred to employ the subspecific rank, but under C. aeolica. In the last years, his proposal has prevailed (Conti \& al. 2005; Greuter 2006; Hilpold \& al. 2011; Anzalone \& al. 2010; Peruzzi \& al. 2015; Pignatti 2018; WCSP 2021). However, Arrigoni (2003), Del Guacchio \& al. (2019), and Brullo $\&$ al. (2021) treated again C. pandataria at the specific level. Therefore, the status remains uncertain; indeed, recent molecular analyses were not able to clarify the phylogenetic relationships of this taxon (Hilpold 2014). For this reason, we re-examined the question including further considerations from literature, clarifying the correct citation of the name and reporting the first chromosome count for this taxon.

\section{Material and Methods}

The present contribution is based on both analysis of the relevant literature (including protologues) and examination of specimens at CAT, FI, GDOR, GE, NAP, P, and PAD (herbarium codes according to Thiers 2021 onwards) and in field during 2017-2019. The articles cited throughout the text follow the Shenzhen Code (Turland \& al. 2018, hereafter ICN).

The chromosomal observations were made on root tips obtained from the cypselae by germination. The root tips were pre-treated with $0.4 \%$ colchicine for 4 hours and then fixed in Carnoy fixative solution for 1 hour. After hydrolysis in $1 \mathrm{~N} \mathrm{HCl}$ at $60^{\circ} \mathrm{C}$ for $7 \mathrm{mins}$, the tips were stained with leukobasic fuchsin. Root tips were then soaked in $45 \%$ acetic acid, macerated and squashed. Metaphasic plates were observed for 3 different individuals, using a Nikon Eclipse Ci-L microscope.

\section{Results and Discussion}

\section{Nomenclature and considerations on the lectotype}

Despite the most widespread opinion (e.g., Greuter 2006; PFI 2021; Brullo \& al. 2021), the name $C$. cineraria var. pandataria is to be attributed only to Fiori, who cured the treatment of Compositae in Flora Analitica d'Italia (Fiori 1904a: 193). In fact, even if Fiori (1904a) reports "Fiori et Bég." in the protologue, there is no evidence that the description of the variety was provided by others than Fiori himself. This statement is further supported by Fiori and Béguinot themselves in herbarium cards (FI, see below). Therefore, according to Art. 46.5 of ICN, the correct citation for the authorship is "Fiori \& Bég. ex Fiori" or simply "Fiori", as already proposed for similar cases (e.g., Del Guacchio \& al. 2021). The name has been recently typified (Brullo $\&$ al. 2021). Fiori (1904a) explicitly alluded in the protologue to the "Bég. hb.", i.e. the private herbarium of Augusto Béguinot. At PAD, where the main part of the collection by Béguinot is preserved, two pertinent sheets are kept. Other pertinent specimens of the Béguinot's herbarium were found at FI, and are filed with the following codes (the specimens in braces were attached on a single sheet when incorporated into the herbarium of Stéphen Sommier): \{FI-051937, FI051938\}, FI-051939, \{FI-051940, FI-051941\}. The above-indicated specimens at PAD and FI (no other specimens were located at GE or GDOR), although belonging to different gatherings (between May 20, 1900 and September 20, 1901), and even if cited in the protologue only by a 
472 Del Guacchio \& al.: Further remarks on the narrow endemic Centaurea pandataria...

generic reference to the herbarium of Béguinot, are syntypes according to Art. 9.5 of ICN. However, there is no proof that the specimens at PAD were ever examined by Fiori, whereas the label on FI-051938 adds a relevant detail: Fiori revised FI-051937, FI-051938, FI-051940, and FI-051941 only in 1912. On the contrary, FI-051939 was incorporated into the personal herbarium of Adriano Fiori. On the original label, Béguinot wrote "Centaurea aplolepa var. meridionalis Nobis?" (evidently an unpublished varietal name, not found elsewhere); while Fiori barred the word "meridionalis" and wrote "pandataria". Brullo \& al. (2021) chosen FI-051939 as the lectotype. After the clarification about the authorship of the name, this is a very agreeable choice. In fact, even if Art. 9.4 (c) does not impose that the author had seen the lectotype, FI-051939 is the only specimen personally revised by Fiori before the publication of the protologue and moreover it includes representative material (a complete fruiting individual, a basal rosette, and a small plant with some flowers and cypselae).

\section{Chromosome number}

According to our results (Fig. 2), counts of three different individuals indicate that $C$. pandataria is diploid $(2 n=18)$, as the other representatives of $C$. cineraria group, among which C. aeolica Guss. ex Lojac. (Cela-Renzoni \& Viegi 1982; Bedini \& Peruzzi 2021).

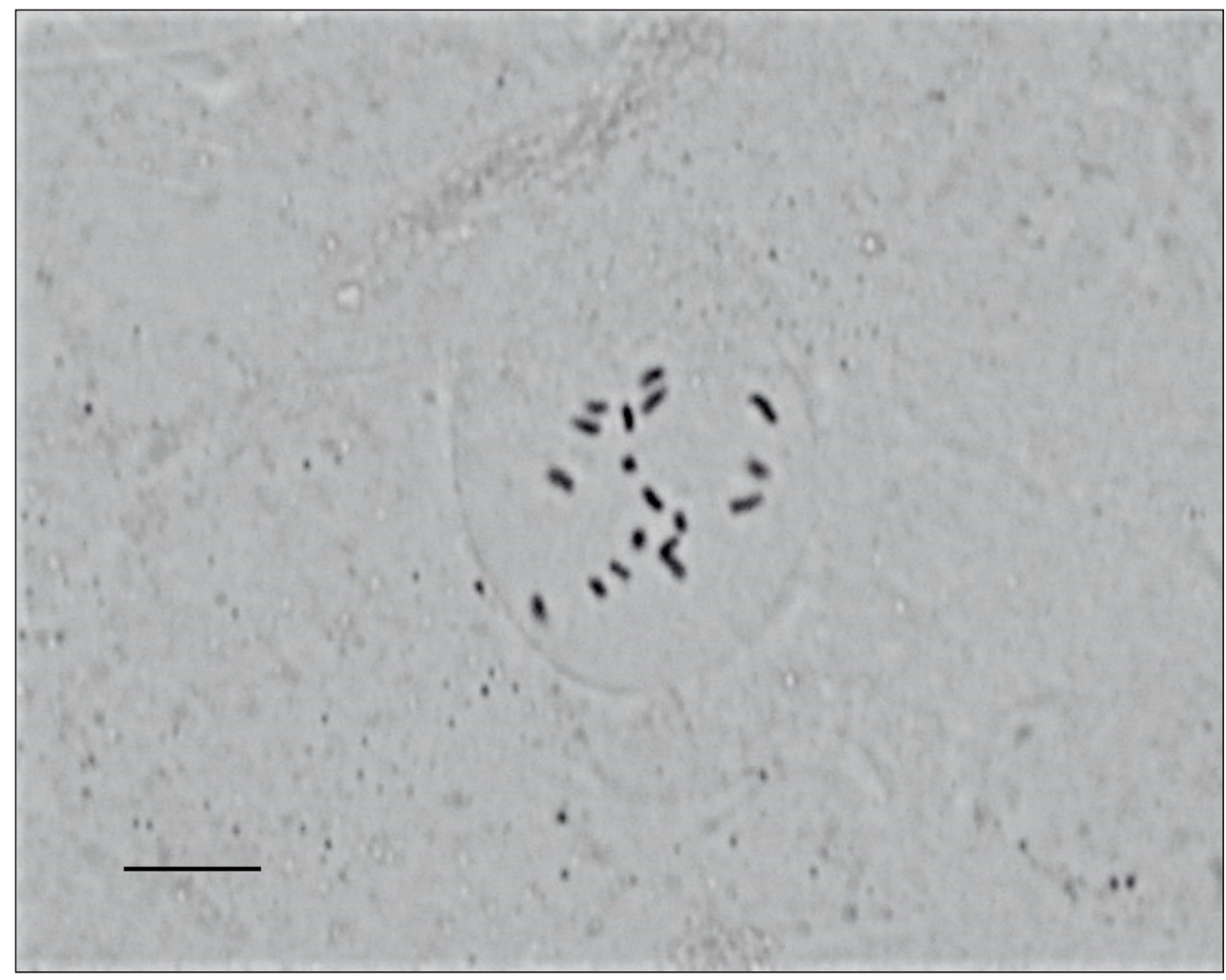

Fig. 2. Metaphase plate representative of three counts on three different individuals of C. pandataria. The bar equals $10 \mu \mathrm{m}$. 


\section{Phylogenetic hypotheses}

As the indications of $C$. aeolica for Ischia island (Gulf of Naples, Campania, southern Italy) (e.g., Pignatti \& Lausi 1982; Hilpold \& al. 2011; Peruzzi \& al. 2015; cf. Ricciardi $\&$ al. 2004) are to be referred to escaped plants (cf. Gussone 1855 sub C. aplolepa) (Del Guacchio \& al. 2019), the geographical separation between the very local $C$. pandataria and the other taxa of the $C$. aeolica group is remarkable (Brullo \& al. 2021). The most likely explanation for this fragmentation is probably a single long-distance dispersal event. It is to be noted that, within the southern Tyrrhenian Sea, the emerged portion of the earliest Aeolian islands appeared around 450,000-400,000 ya (Branca 2014), and Ventotene is even more ancient (Bergomi \& al. 1967); while the volcanic Phlegrean Islands (which are geographically intermediate between the two archipelagos) are much more recent (Aiello \& al. 2007).

In any case, $C$. aeolica is the closest relative of $C$. pandataria. According to a first and simpler hypothesis, $C$. pandataria could have originated as a local differentiation by dispersal from $C$. aeolica or its ancestor. However, as already noted for another controversial group in Centaurea (e.g., Santangelo \& al. 2017), possibly hybridization may have played a role in differentiating local morphs. Also according to our molecular data (not shown), C. aeolica and C. pandataria are very close, in agreement with Hilpold (2011), and represent an outgroup to a clade including $C$. cineraria.

\section{Conclusions and taxonomic treatment}

Several considerations convinced us that, at the present status of knowledge, the specific rank for this taxon is probably the most correct: (1) a remarkable separation between the native ranges of the Aeolian and the Ventotene populations; (2) a trend towards geographical fragmentation of the genus along the Mediterranean coasts (e.g., Hilpold \& al. 2014); (3) the perfect separation of the two taxa according to AFLP analysis (Hilpold 2011); (4) the constancy of differential characters which allow to discriminate between them (Anzalone 1995; Brullo \& al. 2021).

\section{References}

Aiello, G., Barra, D., De Pippo, T., Donadio, C., \& Petrosino, C. 2007: Geomorphological evolution of Phlegrean volcanic islands near Naples, southern Italy. - Z. Geomorph. 51(2): 165-190. https://doi.org/10.1127/0372-8854/2007/0051-0165

Anzalone, B. 1984: Prodromo della Flora Romana (Elenco preliminare delle piante vascolari del Lazio). - Roma.

- 1995: A proposito di una Centaurea L. dell'Isola di Ventotene (Isole Ponziane - Lazio). - Boll. Soc. Sarda Sci. Nat. 30: 511-515.

— \& Caputo, G. 1976: Flora e Vegetazione delle Isole Ponziane (Golfo di Gaeta). - Delpinoa n. s. 16-17: 3-185.

—, Iberite, M. \& Lattanzi, E. 2010: La Flora vascolare del Lazio. - Inform. Bot. Ital. 42: 187-137.

Arrigoni, P. V. 2003: Le Centauree Italiane del gruppo "Centaurea paniculata L.". - Parlatorea 6: 49-78. 
474 Del Guacchio \& al.: Further remarks on the narrow endemic Centaurea pandataria...

Bedini, G. \& Peruzzi, L. (eds) 2021 onwards: Chrobase.it - Chromosome numbers for the Italian flora v. 2.0. - Available from: http://www.biologia.unipi.it/chrobase/ [Last accessed 18 December 2021].

Béguinot, A. 1902: L'Arcipelago Ponziano e la sua flora. Appunti di geografia storica e di topografia botanica. - Boll. Soc. Geogr. Ital. 39: 214-243, 339-370, 408-438.

— 1905: La vegetazione delle isole ponziane e napoletane. - Ann. Bot. (Rome) 3: 181-453.

— 1931: Uno sguardo sintetico alle minori isole italiane. - Nuovo Giorn. Bot. Ital. n. s. 38: 558-559.

Bergomi, C., Catenacci, V., Cestari, G., Manfredini, M. \& Manganelli, V. 1967: Note illustrative della Carta Geologica d'Italia alla Scala 1: 100.000 - Foglio 171: Gaeta e Roccamonfina. Ercolano (Napoli).

Branca, S. 2014: IV - Vulcanismo. - Pp. 323-349 in: Lentini, F. \& Carbone, S. (eds), Geologia della Sicilia. - Memorie descrittive della Carta Geologica d'Italia 95.

Brullo, S., Cambria, S., Crisafulli, A., Tavilla, G. \& Scialandrello, S. 2021: Taxonomic remarks on the Centaurea aeolica (Asteraceae) species complex. - Phytotaxa 483: 9-24. https://doi.org/10.11646/phytotaxa.483.1.2

Cela-Renzoni, G. \& Viegi, L. 1982: Centaurea cineraria s.l. (Asteraceae) in Italia: Revisione citotassonomica. - Atti Soc. Tosc. Sci. Nat. Pisa, Mem., Ser. B, 39: 99-144.

Cennamo, P., Del Guacchio, E., Paino, L., De Castro, O., Menale, B., Vazquez-Torres, M. \& Caputo, P. 2013: Genetic structure of Ipomoea imperati (Convolvulaceae) in the Mediterranean region and implications for its conservation. - Phytotaxa 141: 40-54. http://dx.doi.org/10.11646/phytotaxa.141.1.3

Conti, F., Abbate, G., Alessandrini, A. \& Blasi, C. (eds) 2005: An annotated checklist of the Italian vascular flora. - Roma.

De Castro, O., Vallariello, R. \& Del Guacchio, E. 2013: Integration of morphology, genetics, historical and ethnobotanical data: a case of an enigmatic Genista (Fabaceae) from Ischia Island (southern Italy). - Phytotaxa 82: 64-68. http://dx.doi.org/10.11646/phytotaxa.82.2.2

Del Guacchio, E., Cambria, S. \& Brullo, S. 2021: Typification of the name Ephedra nebrodensis (Ephedraceae). - Phytotaxa 496: 90-92. https://doi.org/10.11646/phytotaxa.496.1.5

—, Cennamo, P. \& Caputo, P. 2019: Sulla presenza di Centaurea aeolica e C. aplolepa (Asteraceae) in Campania. - Notiz. Soc. Bot. Ital. 3: 11-12.

—, Innangi, M., Giacò, A., Peruzzi, L. \& Caputo, P. 2020. Taxa endemic to Campania (southern Italy): nomenclatural and taxonomic notes. - Phytotaxa 449: 217-231. https://doi.org/10.11646/phytotaxa.449.3.2

Dostál, J. 1976: New nomenclatural combinations and taxa of the Compositae subtribe Centaureinae in Europe. - In: Heywood V. H. (ed.), Notulae Systematicae ad Flora Europaeam spectantes, No. 18. - Bot. J. Linn. Soc. 71: 191-210.

Fiori, A. 1904a: Centaurea L. - Pp. 321-349 in: Fiori, A. \& Paoletti, G. (eds), Flora analitica d'Italia, 3. - Padova.

— 1904b: Entità nuove di composite italiane descritte nella "Flora Analitica d'Italia". Nota II ${ }^{\mathrm{a}}$. - Boll. Soc. Bot. Ital. Anno 1904: 96-108.

- 1927: Nuova Flora analitica d'Italia, 2(5). - Firenze.

Grande, L. 1924: Note di floristica. - Nuovo Giorn. Bot. Ital., n. s., 31(2): 105-160.

Greuter, W. 2006+: Compositae (pro parte majore). - In: Greuter, W. \& Raab-Straube, E. von (eds), Compositae. Euro+Med Plantbase]. - http://ww2.bgbm.org/EuroPlusMed/ PTaxonDetail.asp?NameId=135137\&PTRefFk=7000000 [Last accessed 07/04/2021].

Gussone, G. 1855 [“1854”]: Enumeratio plantarum vascularium in insula Inarime. - Neapoli.

Hilpold, A., Schönswetter, P., Susanna, A., Garcia-Jacas, N. \& Vilatersana, R. 2011: Evolution of the central Mediterranean Centaurea cineraria group (Asteraceae): Evidence for relatively recent, allopatric diversification following transoceanic seed dispersal. - Taxon 60: 528-538. 
—, Vilatersana, R., Susanna, A., Meseguer, A. S., Boršić, I., Constantinidis, T., Filigheddu, R., Romaschenko, K., Suárez-Santiago, V. N., Tugay, O., Uysal, T., Pfeil, B. E., Garcia-Jacas, N. 2014: Phylogeny of the Centaurea group (Centaurea, Compositae) - geography is a better predictor than morphology. - Mol. Phylogenetics Evol. 77: 195-215. http://dx.doi.org/ 10.1016/j.ympev.2014.04.022

Iamonico, D., Vallariello, R. \& Del Guacchio, E. 2017: Nomenclatural and distributional remarks on Limonium tenoreanum (Plumbaginaceae), a narrow endemic from southern Italy. - Nord. J. Bot. 35: 445-448. http://dx.doi.org/ 10.1111/njb.01313

Peruzzi, L., Domina, G., Bartolucci, F., Galasso, G., Peccenini, S., Raimondo, F. M., Albano, A., Alessandrini, A., Banfi, E., Barberis, G., Bernardo, L., Bovio, M., Brullo, S., Brundu, G., Brundu, A., Camarda, I., Carta, L., Conti, F., Croce, A., Iamonico, D., Iberite, M., Iiriti, G., Longo, D., Marsili, S., Medagli, P., Pistarino, A., Salmeri, C., Santangelo, A., Scassellati, E., Selvi, F., Soldano, A., Stinca, A., Villani, M., Wagensommer, R. P. \& Passalacqua, N. G. 2015: An inventory of the names of vascular plants endemic to Italy, their loci classici and types. Phytotaxa 196: 1-217. http://dx.doi.org/10.11646/phytotaxa.196.1.1

PFI. 2021: Portal to the Flora of Italy. - http:/dryades.units.it/floritaly [Last accessed 19/03/2021]

Pignatti, S. 2018: Flora d'Italia, ed. 2, 3. - Milano.

— \& Lausi, D. 1982: Centaurea L. - Pp. 173-209 in: Pignatti, S. (ed.), Flora d'Italia, 3. - Bologna.

Santangelo, A., Del Guacchio, E., Cennamo, P. \& Caputo, P. 2017. Reassembling the Centaurea tenorei group (Asteraceae) puzzle: typification of the names. - Phytotaxa 298: 119-133. https://doi.org/10.11646/phytotaxa.298.2.2

Thiers, B. 2021 onwards: Index Herbariorum: A global directory of public herbaria and associated staff. New York Botanical Garden's Virtual Herbarium. - http://sweetgum.nybg.org/ih/ [Last accessed 8 March 2021].

Turland, N. J., Wiersema, J. H., Barrie, F. R., Greuter, W., Hawksworth, D. L., Herendeen, P. S., Knapp, S., Kusber, W.-H., Li, D.-Z., Marhold, K., May, T. W., McNeill, J., Monro, A. M., Prado, J., Price, M. J. \& Smith, G. F. (eds) 2018: International Code of Nomenclature for algae, fungi, and plants (Shenzhen Code) adopted by the Nineteenth International Botanical Congress Shenzhen, China, July 2017. - Regnum Veg. 159: 1-254. https://doi.org/10.12705/Code. 2018

Vallariello, R., Iamonico, D. \& Del Guacchio, E. 2016: Typification of three accepted names in Limonium (Plumbaginaceae). - Phytotaxa 263: 131-138. http://dx.doi.org/10.11646/phytotaxa.263.2.5

WCSP 2021 onwards: World Checklist of Selected Plant Families. - http://wcsp.science.kew.org/ [ Last accessed 8/03/2021].

Zangheri, P. 1976: Flora Italica, 1. - Padova.

Addresses of the authors:

Paolo Caputo ${ }^{1 *}$, Emanuele Del Guacchio ${ }^{1}$ Luca Paino $^{1} \&$ Paola Cennamo ${ }^{2}$,

${ }^{1}$ Dipartimento di Biologia; Orto Botanico di Napoli. Università degli Studi di Napoli

Federico II, Via Foria 223, I-80139, Napoli, Italy.

${ }^{2}$ Dipartimento di Scienze Umanistiche. Università degli Studi Suor Orsola

Benincasa. Via S. Caterina, I-80132 Napoli, Italy.

*Corresponding author, E-mail: pacaputo@unina.it. 
